\title{
Effect of drying temperature on color and desorption characteristics of oyster mushroom
}

\author{
Demiray Engin ${ }^{1 *}($ (D)
}

\begin{abstract}
Oyster mushroom (Pleurotus ostreatus) slices were dried in a hot air dryer at three temperatures $\left(45,55\right.$ and $\left.65^{\circ} \mathrm{C}\right)$. The sorption isotherm of dried samples in the water activity $\left(a_{\mathrm{w}}\right)$ range of $0.556-0.970$ was also determined at three temperature levels. Moisture desorption isotherms were obtained from changes in water activities of oyster mushroom slices during drying, and the fitness of GAB, BET, Oswin, Henderson and Halsey isotherm equations to sorption data was calculated. The effect of temperature on color change kinetics of oyster mushroom slices was also investigated during drying. GAB model was the best equation for the prediction of the desorption moisture content of samples. Mathematical modeling of color change kinetics indicated that both zero and first order kinetic models were adequate to describe the browning index (BI) value; however, total color change $(\Delta \mathrm{E})$ followed zero-order kinetics. The values of the reaction rate constant, found after the drying at 45,55 and $65{ }^{\circ} \mathrm{C}$, of the $\Delta \mathrm{E}$ value were respectively $0.058,0.065$ and 0.089 .
\end{abstract}

Keywords: oyster mushroom; drying; sorption isotherm; GAB model; color.

Practical Application: Determination of sorption isotherms of oyster mushroom slices and color degradation in mushroom samples during drying.

\section{Introduction}

At the present time, thanks to the fact that the importance of mushrooms for the human nutrition and health has come to be understood, there has been an increase in the interest in fungiculture (Politowicz et al., 2018). Pleurotus ostreatus (the oyster mushroom) is the second most cultivated mushroom after Agaricus bisporus; and it, besides its economic and ecological value, has medical aspects too (Usami et al., 2015). Some researchers have stated that with the hypoglycemic and antithrombotic activities it stops tumor cell growth and inflammation, lowers the concentration of blood lipids, prevents high blood pressure and embolism and that it has antimicrobial activities. Due to its low amount of fat, it is recommended as a dietary food (Chang \& Miles, 2004). Jwanny et al. (1996) has asserted that as a solution to the problems stemming from the excessive consumption of animal products made up of high cholesterol and saturated fat, especially in developed countries, the diet must be immediately and radically changed, and it can be ensured through herbal products and mushrooms specifically.

Drying, one of the methods for preserving agricultural products to keep the quality and against decaying, is the oldest and the most broadly-practiced method. It is this method that is the most practiced though it is possible to preserve agricultural products for an extended period of time by means of cooling, freezing, exposing them to chemical processes, stocking them in an anaerobic environment, making use of ultraviolet and radioactive beams. Mushroom can easily and quickly decay owing to its content of high humidity and is a product that has shelf life of seven to ten days in cold storage. It is conserved and dried so as to prolong the shelf life (Bano et al., 1992; Rama \& Jacob John, 2000). Thanks to the operation of drying, there are significant advantages in the costs of transportation, storing and packaging, paralleling the decrease in weight and volume of mushrooms. Moreover, as it is very easy to mix these with other dried products, the area of its use is extensive. Dried mushrooms are generally used in sauces, instant soups and convenience foods (Yapar et al., 1990).

Color is an important component of quality throughout agriculture and food industry, because it plays an important role in the attractiveness of foods, in terms of consumer preference. During the drying of foods, color pigments are oxidized by thermal decomposition. In general, long drying times and high temperatures increase pigment degradation and cause more variation in the color of dried foods. The color change kinetics of foods is a complex phenomenon, and there are not much reliable models to predict color change, which can be used in engineering calculations (Suh et al., 2003; Ahmed et al., 2000).

The predictability of the exchange of humidity between foods and their surroundings is of utmost importance since it determines the stability of foods, thus affecting their shelf life. Humidity sorption isotherms help to specify the relationship between the water activity of food products and their equilibrium relative humidity under a certain heat and pressure, and they reveal details about such food processes as drying, mixing, packaging and storing. The basic approach taken on to specify the humidity sorption isotherms of foods is to monitor statically and dynamically the conditions in which a food is kept in closed environments which have different water activity values under a stable heat, and the weight changes resulting from water vapor gain or loss. Many sorption equations that pay regard to the relationship between water activity, the humidity of a food and 
the binding energy of water have been developed such as GAB (Guggenheim-Anderson-deBoer), BET (Braunauer, Emmett and Teller), Simit, Halsey, Henderson, Henderson, Oswin and Langmuir. Nonetheless, these equations cannot represent all foods adequately, and it is due to the high rate of structural heterogeneity of foods as a compound. On the other hand, the BET equation, one of the earliest sorption equations and widely utilized, can capably represent the isotherm if the water activity is below 0.50 . And it is also accepted that the GAB equation, which is about characteristics of the water, can efficiently represent sorption isotherms of foods up to 0.90 (Sahin \& Sumnu, 2006).

The present work aimed at studying the effect of hot air drying at different temperatures on the color preservation and the sorption isotherms of oyster mushroom. The three Hunter parameters redness (a), yellowness (b) and lightness (L) were used to estimate browning during drying, while some isotherm models were used to describe sorption isotherms.

\section{Material and methods}

\subsection{Material}

Oyster mushrooms of the Pleurotus genus (Pleurotus ostreatus) were used in drying experiments. Visually fresh and equally ripen mushrooms of were supplied by a local grower in the district of Korucuk, Pamukkale, Denizli. Mushrooms were cooled immediately and brought to the Department of Food Engineering where the process of drying was conducted in the Faculty of Engineering at Pamukkale University. They were kept at $4{ }^{\circ} \mathrm{C}$, and mushrooms with similar sizes were selected for drying experiments.

\subsection{Methods}

\section{Hot air drying}

The hot air drying experiments were conducted at temperatures of 45,55 and $65^{\circ} \mathrm{C}$ in a hot air dryer (Yücebaş Makine Ltd. Inc., İzmir, Turkey). It consists of a centrifugal fan to supply the air flow, an electric heater and an electronic proportional controller. The dryer included four removable trays of $40 \times 60 \mathrm{~cm}$, which are made of stainless steel gauze formed into a fine sieve. Prior to hot air drying, samples were taken out of refrigerator, oyster mushrooms were washed and sliced in thickness of $6.5 \pm 1 \mathrm{~mm}$ using a sharp knife. About $500 \mathrm{~g}$ of oyster mushroom slices were weighed and placed on trays as a single layer. During hot air drying, weight of the sample was recorded regularly. In addition, samples were taken from the trays on regular basis for further analyses. The hot air drying was applied until the weight of sample reduced to a level corresponding to moisture content of about $15 \mathrm{~g} / 100 \mathrm{~g}$. At all drying experiments, a constant airflow of $0.2 \mathrm{~m} / \mathrm{s}$ and a constant $20 \%$ relative humidity was used. The hot air dryer was started at about $1 \mathrm{~h}$ before the drying experiments to stabilize both temperature and relative humidity. Three replicates for each of the experiment were done.

\section{Color measurement}

During the study in which the drying process was carried out to analyze the impact of the oyster mushrooms on color change, the color values of the samples taken at pre-determined certain intervals during the drying process were measured with the color measuring device (Hunter Associates Laboratory, Model: MiniScan XE, the USA). In Hunter L, a, b color coordinate system the $\mathrm{L}$ value stands for lightness and its extent varies between 0 and 100 . Hunter $\mathrm{a}$ and $\mathrm{b}$ values which are color coordinates do not have a certain extent of measure, and when the a value is positive, it expresses the color red; when it is negative, it means the color green. When the Hunter $b$ value is positive, it shows the color yellow, and when it is negative, it indicates the color blue.

Measured Hunter L, a and b values do not fully represent the color perception of the consumer while providing information about the basic components of the product color. For this reason, the color criteria which address to consumer's perception of color such as the Hue Angle ( $\left.{ }^{\circ}\right)$, i.e. the angle of color tone, the chroma value, the total color difference $(\Delta \mathrm{E})$ and the browning index (BI) were measured as, respectively, Equations 1-4. The Hue Angle $\left({ }^{\circ}\right)$ is defined as a color circle and its red-violet colors are between $0^{\circ}-270^{\circ}$, the color yellow $60^{\circ}$ and the value between blue and green is $240^{\circ}-120^{\circ}$. The chroma value shows the color saturation. With dull colors the chroma value decreases whereas it is the opposite when with vivid colors.

$$
\Delta \mathrm{E}=\sqrt{(\Delta \mathrm{L})^{2}+(\Delta \mathrm{a})^{2}+(\Delta \mathrm{b})^{2}}
$$

Hue Angle $\left({ }^{\circ}\right)=\tan ^{-1}\left(\frac{b}{a}\right)$

Chroma $=\left(a^{2}+b^{2}\right)^{1 / 2}$

$\mathrm{BI}=[100(\mathrm{x}-0.31)] 0.17$

Where, $x=(a+1.75 \mathrm{~L})(5.645 \mathrm{~L}+\mathrm{a}-3.012 \mathrm{~b})$

Before the color measurements were conducted, Hunterlab MiniScan XE color measurement device (Hunter Associates Laboratory, Reston, USA) was calibrated through black and white standard calibration tiles. Color measurements were carried out at three different points and evaluated according to the averages of the values.

\section{Kinetics models of color degradation}

In the study, the kinetics of color changes in oyster mushrooms during drying of oyster mushrooms at different temperatures was studied. At all temperatures studied, it was scrutinized whether color change reactions occurred in accord with the zero-order reaction or the first-order reaction. The equation 5 for the zero-order reaction and the equation 6 for the first-order reaction were used. For every temperature applied, the color values, with their Napierian logarithms taken, were placed on the " $y$ " axis and the times were directly put on the " $\mathrm{x}$ " axis; this way, a linear curve on a natural scale graphic was obtained. By applying linear regression analysis to this curve, the equation of the curve was calculated, and the slope value of the equation procured directly reveals the rate constant of the reaction. 
$\mathrm{A}=\mathrm{A}_{0}+\mathrm{k}_{0} \mathrm{t}$

$\mathrm{A}=\mathrm{A}_{0} \exp \left(\mathrm{k}_{1} \mathrm{t}\right)$

Where $A$ is the studied parameter $(B I$ and $\Delta \mathrm{E})$ at any given drying time, $A_{0}$ are initial values of untreated samples $k_{0}$ and $k_{1}$ are rate constants for the zero- and first-order reactions, respectively.

The degree of dependence on the temperature of the reaction was specified through the calculation of both $Q_{10}$ and the activation energy $\left(E_{a}\right)$. The relationship between the reaction velocity and temperature came to be defined by Arrhenius in 1889, and it, still valid in the present time, is in the Equation 7.

$\mathrm{k}=\mathrm{k}_{\mathrm{a}} \exp \left(-\frac{\mathrm{E}_{\mathrm{a}}}{\mathrm{RT}}\right)$

where $k$ is the rate constant at temperature $T(\mathrm{~K}), k_{a}$ is the frequency factor, $E_{a}$ is the activation energy $\left(\mathrm{Jmol}^{-1}\right)$, and $R$ is the universal gas constant $\left(8.314 \mathrm{Jmol}^{-1} \mathrm{~K}^{-1}\right)$.

The $\mathrm{Q}_{10}$ value, another kinetic coefficient that shows the dependence of the reaction on temperature, is a criterion showing the effect of increasing the temperature by $10^{\circ} \mathrm{C}$ on the reaction velocity and it was calculated thanks to the Equation 8.

$\mathrm{Q}_{10}=\left(\mathrm{k}_{2} / \mathrm{k}_{1}\right)^{10 /\left(\mathrm{T}_{2}-\mathrm{T}_{1}\right)}$

Where $k_{1}$ and $k_{2}$ are reaction rate constants at temperatures $T_{1}$ and $T_{2}$, respectively $\left(\mathrm{min}^{-1}\right)$.

The experimental results are expressed as mean \pm standard deviation of triplicate measurements and results were processed using Microsoft Excel (Microsoft Office 2016, Washington, USA).

\section{Water activity measurements}

The water activities of the samples of fresh and dried oyster mushrooms were determined by using the water activity measuring device (GBX, Fast-Lab, France) that has \pm 0.001 sensitivity. This end, about 3-4 grams of the sample shredded was swiftly placed into the stainless steel chamber of the device. After five minutes, the water activity on the indicator of the device was read.

\section{Determination of desorption isotherms}

The experimental moisture content and water activity obtained were investigated by B.E.T., Oswin, Halsey, Henderson and G.A.B. mathematical models were used. The equations belonging to these five models are given in (Table 1).

The root mean square error (RMSE), through the model, presents the deviation between the estimated values and the experimental values. Moreover, it is stated that the less the reduced chi-square $\left(\chi^{2}\right)$ value, the more the suitability (Midilli et al., 2002).

RMSE and $\chi^{2}$ values were calculated according to the Equations 9 and 10, respectively. Microsoft Excel was used during calculations.

$$
\begin{aligned}
& \text { RMSE }=\left[\frac{1}{N} \sum_{i=1}^{N}\left(M_{\text {exp }, i}-M_{\text {pre }, i}\right)^{2}\right]^{1 / 2} \\
& \chi^{2}=\frac{\sum_{i=1}^{N}\left(M_{\text {exp }, i}-M_{\text {pre }, i}\right)^{2}}{N-z}
\end{aligned}
$$

Where $M_{\text {exp, } i}$ is the $i$ th experimentally observed moisture content, $M_{\text {pre }, i}$ is the $i$ th predicted moisture content, $N$ is the number of observation and $z$ is the number constants (Madamba et al., 1996).

The best model describing the desorption behaviour of oyster mushrooms were chosen as the one with the highest coefficient of determination and the least mean relative percent error and the least root mean square error. In addition, reduced chi-square was used to determine the goodness of the fit. The lower values of reduced chi-square, the better goodness of the fit.

\section{Statistical analysis}

The data obtained as a result of two parallel and three replications were analyzed by using SPSS statistical package program (version 17, SPSS Inc., Chicago, IL, USA). Duncan's multiple range tests $(\mathrm{p}<0.05)$ was used to compare the average responses between treatments.

Table 1. Desorption models for experimental data fitting.

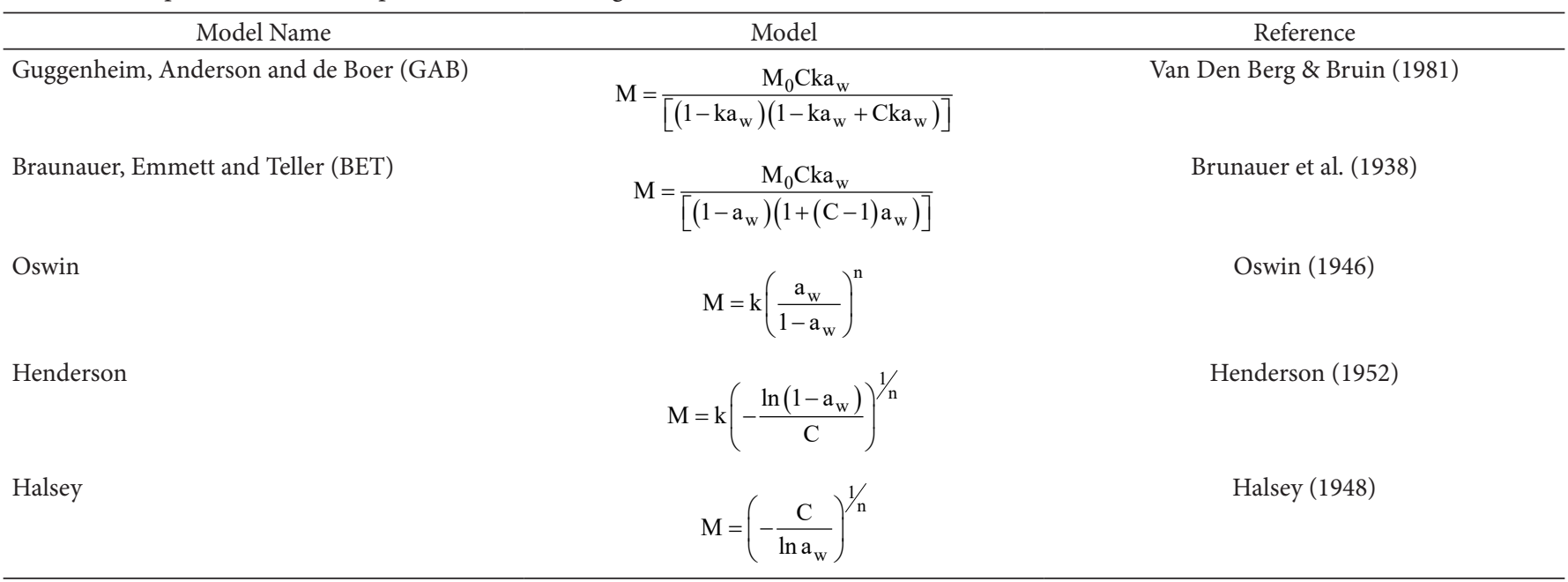




\section{Results and discussion}

\subsection{Desorption isotherms}

Before launching the process, the first moisture content of the samples of oyster mushrooms used in the experiments were detected by drying it in the drying oven at $70 \pm 1{ }^{\circ} \mathrm{C}$ for 24 hours. The dry matter ratio was calculated to be $15.52 \pm 0.5 \%$ and the first moisture content $5.44 \pm 0.02 \mathrm{~kg}$ water $/ \mathrm{kg}$ dry matter (Association of Official Analytical Chemists, 1990). The initial water activity value was 0.981 . Desorption isotherms were determined at three different temperatures $\left(45,55\right.$ and $\left.65^{\circ} \mathrm{C}\right)$ during the drying process of sliced oyster mushrooms and the results obtained were given in Table 2 . Moisture contents of the samples that reached the equilibrium moisture were transferred to an arithmetically-scaled diagram against the water activities of the samples and their desorption isotherms were specified (Figure 1A-C). Water activity and the forms of sorption isotherms are affected by food composition and system temperature (Kostaropoulos \& Saravacos, 1995). As seen in Figure 1, in all the water activity values, as the temperature goes up, the equilibrium moisture content goes down. It is generally accepted that with the increase in temperature, the equilibrium moisture content gradually decreases (Okos et al., 1992).

Many mathematical models have been utilized to define the moisture sorption behaviours of foods. In this study, the applicability to five models were scrutinized. The parameters, belonging to those models, of the sliced oyster mushrooms were calculated during the drying, and are in Table 3. As is seen in Table 3, the parameters of the models change in accord with the temperature. In addition to constants and coefficients of the theoretical models used in the study in the table, the $\mathrm{RMSE}, \chi^{2}$ and $\mathrm{R}^{2}$ values are presented. With the data taken into consideration, it was determined that the GAB model which had the highest $\mathrm{R}^{2}$ and lowest RMSE values was the best model to define the moisture sorption of the oyster mushroom sample. The graphical display of the comparison between the experimental values as regards the change of the moisture content values due to water activity at each temperature during the drying operation and the values from the models made use of is in Figure 1A-C. It is clearly seen that there are similar results in other studies of modelling the moisture sorption behaviours in the literature. A work conducted by Park et al. (2002) on the moisture sorption data of garden mint leaves proposed the GAB equations as the most appropriate to describe their desorption isotherms. Similarly, the GAB equation predicted the equilibrium moisture content of dried apples adequately (Prothon \& Ahrne, 2004).

Table 2. Desorption isotherms of oyster mushroom slices at different temperature.

\begin{tabular}{cccccccc}
\hline \multicolumn{2}{c}{$\mathbf{4 5}^{\circ} \mathbf{C}$} & & \multicolumn{2}{c}{$\mathbf{5 5}^{\circ} \mathbf{C}$} & & \multicolumn{2}{c}{$\mathbf{6 5}^{\circ} \mathbf{C}$} \\
\cline { 1 - 4 } \cline { 7 - 8 } \cline { 7 - 8 } $\mathbf{a}_{\mathbf{w}}$ & $\mathbf{M}$ & & $\mathbf{a}_{\mathbf{w}}$ & $\mathbf{M}$ & & $\mathbf{a}_{\mathbf{w}}$ & $\mathbf{M}$ \\
\hline 0.597 & 0.107 & & 0.574 & 0.035 & & 0.556 & 0.156 \\
0.700 & 0.463 & & 0.608 & 0.174 & & 0.664 & 0.403 \\
0.836 & 1.012 & & 0.655 & 0.584 & & 0.839 & 0.787 \\
0.897 & 1.763 & & 0.848 & 0.940 & & 0.905 & 1.891 \\
0.954 & 3.289 & & 0.928 & 3.109 & & 0.970 & 3.818 \\
\hline
\end{tabular}

\subsection{Degradation kinetics of color values}

One of the most important quality parameters of dried products is color. Color values of both fresh and dried oyster mushrooms are in Table 4. In a successful drying process, it is required that the samples maintain their color and not brown. In this respect and with all color values taken into consideration, the most preserved color values were of the sample which was dried at $45^{\circ} \mathrm{C}$. Statistically, following the drying at 45,55 and $65^{\circ} \mathrm{C}$, the $L$ values were detected to differ $(\mathrm{p}<0.05)$. A similar situation was valid for the Hue Angle $\left(^{\circ}\right)$ value. The chromas of the samples dried at 55 and $65^{\circ} \mathrm{C}$ statistically bore no difference ( $\mathrm{p}>0.05$ ) when $\mathrm{BI}$ and $\mathrm{b}$ values were examined. The result was in agreement with several researchers who had also reported about color parameters during drying of different types of food
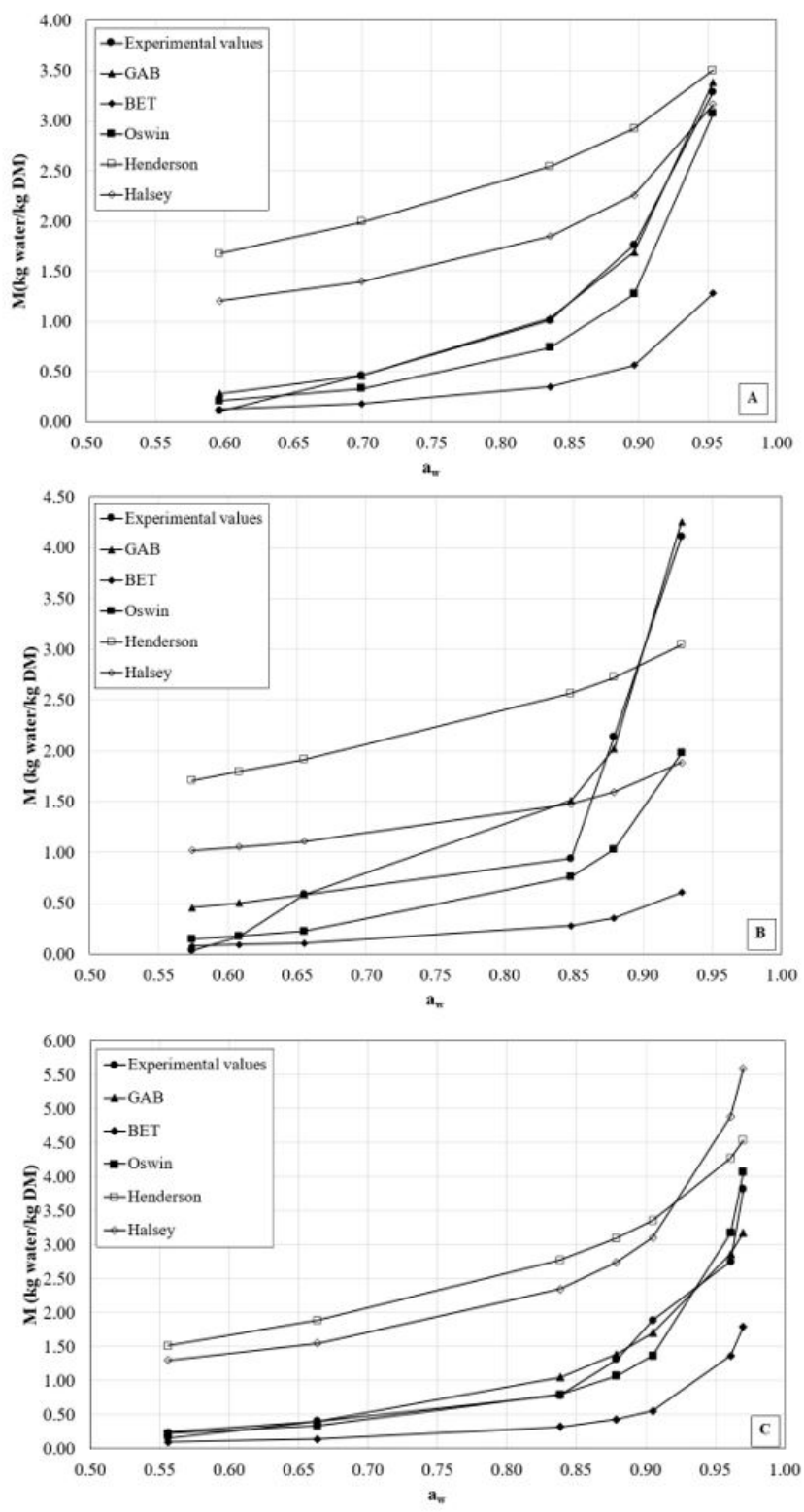

Figure 1. Fits of the various models equations to the experimental desorption isotherms for oyster mushroom slices at (A) $45^{\circ} \mathrm{C}$, (B) $55^{\circ} \mathrm{C}$ and $(\mathbf{C}) 65^{\circ} \mathrm{C}$. 
products such as water melon and Boletus edulis mushroom (Falade et al., 2007; Argyropoulos et al., 2011). The drying process in which the total color change was the highest was the one conducted at $65^{\circ} \mathrm{C}$. The drying at other temperatures were different in terms of color change and the lowest rate was found in the one at $45^{\circ} \mathrm{C}$.

As a result of the modelling studies, while the change of the BI value was fit for the kinetic model both in the zero order and in the first order. The same order of reaction was found by Dadali et al. (2007) and Demirhan \& Ozbek (2009) in basil. $\Delta \mathrm{E}$ value was fit only in the zero order. The results obtained were in agreement with reported literature kiwifruits (Maskan, 2001) and carrots (Demiray \& Tulek, 2015). Mathematical model constants and statistical data were in Table 5 . When the reaction rate constants were analysed, it was observed that the higher the temperature was, the higher these values. For instance, for the zero order reaction model, the values of the reaction rate constant, found after the drying at 45,55 and $65{ }^{\circ} \mathrm{C}$, of the $\Delta \mathrm{E}$ value were respectively $0.058,0.065$ and 0.089 . Activation energy and $\mathrm{Q}_{10}$ values of the color values were calculated by using the reaction rate constant and drying temperature values and given in Table 5. When the activation energy values were studied for the $\Delta \mathrm{E}$ and the $\mathrm{BI}$ values, the activation energy value of the change of the $\Delta \mathrm{E}$ value were higher than that of the $\mathrm{BI}$ value. It reveals that the $\Delta \mathrm{E}$ value is affected more by the change of temperature. When the $\mathrm{Q}_{10}$ values which were

Table 3. Statistical results obtained from the selected models.

\begin{tabular}{|c|c|c|c|c|c|c|c|}
\hline Model & $\begin{array}{c}\text { Temperature } \\
\left({ }^{\circ} \mathrm{C}\right)\end{array}$ & \multicolumn{3}{|c|}{ Model parameters } & $\chi^{2}$ & RMSE & $R^{2}$ \\
\hline \multirow[t]{3}{*}{ GAB } & 45 & $k=0.977$ & $C=0.600$ & $M_{0}=0.260$ & 0.016 & 0.098 & 0.9992 \\
\hline & 55 & $k=1.028$ & $C=0.836$ & $M_{0}=0.196$ & 0.050 & 0.183 & 0.9979 \\
\hline & 65 & $k=0.928$ & $C=0.375$ & $M_{0}=0.131$ & 0.015 & 0.104 & 0.9956 \\
\hline \multirow[t]{3}{*}{ BET } & 45 & & $C=3.892$ & $M_{0}=0.060$ & 4.266 & 1.847 & 0.5706 \\
\hline & 55 & & $C=2.951$ & $M_{0}=0.054$ & 9.997 & 2.886 & 0.5051 \\
\hline & 65 & & $C=3.881$ & $M_{0}=0.045$ & 6.846 & 2.422 & 0.7390 \\
\hline \multirow[t]{3}{*}{ Oswin } & 45 & $k=0.141$ & & $n=1.019$ & 0.336 & 0.449 & 0.9112 \\
\hline & 55 & $k=0.108$ & & $n=1.138$ & 4.718 & 1.773 & 0.7934 \\
\hline & 65 & $k=0.184$ & & $n=0.889$ & 0.001 & 0.027 & 0.9655 \\
\hline \multirow[t]{3}{*}{ Henderson } & 45 & & $C=0.385$ & $n=1.655$ & 12.04 & 2.688 & 0.9662 \\
\hline & 55 & & $C=0.300$ & $n=1.949$ & 3.754 & 1.582 & 0.8536 \\
\hline & 65 & & $C=0.467$ & $n=1.333$ & 21.40 & 3.910 & 0.9848 \\
\hline \multirow[t]{3}{*}{ Halsey } & 45 & & $C=0.824$ & $n=2.478$ & 3.532 & 1.456 & 0.8940 \\
\hline & 55 & & $C=0.594$ & $n=3.267$ & 0.160 & 0.326 & 0.7582 \\
\hline & 65 & & $C=1.000$ & $n=2.031$ & 21.81 & 3.948 & 0.9545 \\
\hline
\end{tabular}

Table 4. Effect of drying temperatures on the color parameters in dried oyster mushroom slices.

\begin{tabular}{cccccccc}
\hline \multirow{2}{*}{ Condition } & \multicolumn{5}{c}{ Color values $^{*}$} \\
\cline { 2 - 7 } & $L$ & $a$ & $b$ & $\Delta \mathrm{E}$ & Chroma & Hue Angle $\left(^{o}\right)$ \\
\hline Fresh & $72.62 \pm 0.51^{\mathrm{a}}$ & $-0.83 \pm 0.11^{\mathrm{a}}$ & $11.11 \pm 0.52^{\mathrm{a}}$ & 0.00 & $11.16 \pm 0.87^{\mathrm{a}}$ & $94.91 \pm 0.85^{\mathrm{a}}$ & $15.35 \pm 0.45^{\mathrm{a}}$ \\
$45^{\circ} \mathrm{C}$ & $67.34 \pm 0.60^{\mathrm{c}}$ & $-0.30 \pm 0.08^{\mathrm{b}}$ & $18.88 \pm 0.33^{\mathrm{b}}$ & $9.07 \pm 0.74^{\mathrm{a}}$ & $18.91 \pm 0.51^{\mathrm{b}}$ & $90.89 \pm 0.47^{\mathrm{c}}$ & $30.01 \pm 0.16^{\mathrm{b}}$ \\
$55^{\circ} \mathrm{C}$ & $71.92 \pm 0.35^{\mathrm{a}}$ & $-1.25 \pm 0.16^{\mathrm{c}}$ & $20.04 \pm 0.40^{\mathrm{c}}$ & $9.56 \pm 0.24^{\mathrm{b}}$ & $20.08 \pm 0.16^{\mathrm{c}}$ & $93.49 \pm 0.20^{\mathrm{a}}$ & $31.73 \pm 0.16^{\mathrm{c}}$ \\
$65^{\circ} \mathrm{C}$ & $70.14 \pm 0.42^{\mathrm{b}}$ & $-0.35 \pm 0.05^{\mathrm{b}}$ & $19.97 \pm 0.22^{\mathrm{c}}$ & $10.09 \pm 0.36^{\mathrm{c}}$ & $20.05 \pm 0.24^{\mathrm{c}}$ & $96.15 \pm 0.41^{\mathrm{b}}$ & $32.28 \pm 0.28^{\mathrm{c}}$ \\
\hline
\end{tabular}

${ }^{\star}$ Results are expressed as mean \pm standard error. Different capital letters in the same column indicate significant differences at $\mathrm{p}<0.05$.

Table 5. The kinetic parameters of $\Delta \mathrm{E}$ and $B I$ values of oyster mushroom slices dried at different temperatures.

\begin{tabular}{|c|c|c|c|c|c|c|c|c|c|}
\hline \multirow[b]{2}{*}{ Color values } & \multirow[b]{2}{*}{$\begin{array}{c}\text { Temperature } \\
\left({ }^{\circ} \mathrm{C}\right)\end{array}$} & \multicolumn{4}{|c|}{ Zero-Order Model } & \multicolumn{4}{|c|}{ First-Order Model } \\
\hline & & $\mathrm{k}_{0}$ & $\mathrm{R}^{2}$ & $\begin{array}{c}\mathrm{Q}_{10} \\
\text { value }\end{array}$ & 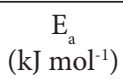 & $\begin{array}{c}\mathrm{k}_{1} \\
\left(\mathrm{~min}^{-1}\right)\end{array}$ & $\mathrm{R}^{2}$ & $\begin{array}{c}\mathrm{Q}_{10} \\
\text { value }\end{array}$ & 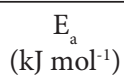 \\
\hline \multirow[t]{3}{*}{$\Delta \mathrm{E}$} & 45 & 0.058 & 0.9810 & 1.21 & 19.05 & 0.010 & 0.9653 & 1.40 & 21.11 \\
\hline & 55 & 0.065 & 0.9908 & 1.37 & & 0.014 & 0.9431 & 1.14 & \\
\hline & 65 & 0.089 & 0.9957 & & & 0.016 & 0.9402 & & \\
\hline \multirow[t]{3}{*}{$B I$} & 45 & 0.132 & 0.9961 & 1.02 & 10.69 & 0.005 & 0.9889 & 1.03 & 10.21 \\
\hline & 55 & 0.134 & 0.9917 & 1.25 & & 0.006 & 0.9890 & 1.22 & \\
\hline & 65 & 0.168 & 0.9920 & & & 0.007 & 0.9833 & & \\
\hline
\end{tabular}


calculated in order to present to what extent the temperature increase had an effect on the rate of change belonging to the color parameters and are also given in Table 5 were analysed, the result was that when the drying temperature was increased from $55^{\circ} \mathrm{C}$ to $65^{\circ} \mathrm{C}$, the impact on the color values was more than when the temperature was increased from $45^{\circ} \mathrm{C}$ to $55^{\circ} \mathrm{C}$. That $\mathrm{Q}_{10}$ value based on $\Delta \mathrm{E}$ value was higher than $\mathrm{BI}$ value when the temperature was changed from $45^{\circ} \mathrm{C}$ to $55^{\circ} \mathrm{C}$ is also visible in Table 5. This outcome manifests that $\Delta \mathrm{E}$ value may have been affected by the temperature increase more, compared to $\mathrm{BI}$ value. The value obtained for the activation energy for drying of oyster mushroom based on change in BI value was $10.69 \mathrm{~kJ} / \mathrm{mol}$ for zero-order and $10.21 \mathrm{~kJ} / \mathrm{mol}$ for first-order reaction model. These values were slightly lower than the value $(44.80 \mathrm{~kJ} / \mathrm{mol})$ given in BI value of oyster mushroom using linearly increasing temperature treatment (Xanthopoulos et al., 2014). The difference in activation values could be due to the variation in the type of treatment or process and compositional change in samples being treated.

\section{Conclusion}

Production costs significantly decrease thanks to the specification of temperature and sorption features in drying operations of agricultural products. In this study, the desorption isotherms of sliced oyster mushrooms during the drying operations at different temperatures $\left(45,55\right.$ and $\left.65^{\circ} \mathrm{C}\right)$ were specified and the applicability to different mathematical models were studied. GAB model was found acceptable for predicting desorption moisture isotherms, while the other models presented a poor fitting to the experimental data. Moreover, during the drying, the changes in colour were identified and the kinetic modelling of the $\Delta \mathrm{E}$ and $\mathrm{BI}$ values was carried out.

The increase in the drying temperature helped to accelerate the drying rate; however, high temperatures are not recommended as they cause browning in the samples which are of importance for the customer preference. Kinetic modelling was conducted for the changes in $\Delta \mathrm{E}$ and $\mathrm{BI}$ values through the values obtained as a result of colour evaluations done at intervals in all the drying process. At the end of the modelling studies; the change of BI value was applicable to the kinetic model both in the zero order and in the first order; the change of $\Delta \mathrm{E}$ value was determined to be applicable only to the zero order kinetic model.

\section{Nomenclature}

$a_{w}$ water activity

$C$ total heat of sorption constant

$E_{\mathrm{a}}$ activation energy $\left(\mathrm{kJ} \mathrm{mol}^{-1}\right)$

$k, k_{0}, k_{1}$ rate constants in models, $\min ^{-1}$

$M$ moisture content, $\mathrm{kg}$ water/kg dry matter

$M_{0}$ monolayer moisture content, kg water/kg dry matter

$N$ number of observations

$n$ model constant
$R^{2}$ determination coefficient

RMSE Root Mean Square Error

$T$ temperature, ${ }^{\circ} \mathrm{C}$

$t$ drying time, min

$\chi^{2}$ reduced chi-square

$z$ number of constants in models

\section{Acknowledgements}

This research was supported by the Pamukkale University Research Fund (2016BSP002).

\section{References}

Ahmed, J., Shivhare, U. S., \& Raghavan, G. S. V. (2000). Rheological characteristics and kinetics of colour degradation green chilli puree. Journal of Food Engineering, 44(4), 239-244. http://dx.doi. org/10.1016/S0260-8774(00)00034-0.

Association of Official Analytical Chemists - AOAC. (1990). Official methods of analysis of the Association of Official Analytical Chemists. Arlington: AOAC.

Argyropoulos, D., Khan, M. T., \& Müller, J. (2011). Effect of air temperature and pre-treatment on color changes and texture of dried Boletus edulis Mushroom. Drying Technology, 29(16), 1890-1900. http://dx.doi.org/10.1080/07373937.2011.594194.

Bano, Z., Rajarathnam, S., \& Shashi Rekha, M. N. (1992). Mushroom as the unconventional single cell protein for a conventional consumption. Indian Food Packer, 46, 20-31.

Brunauer, S., Emmett, P. H., \& Teller, E. (1938). Adsorption of gases in multimolecular layers. Journal of the American Chemical Society, 60(2), 309-319. http://dx.doi.org/10.1021/ja01269a023.

Chang, S. T., \& Miles, P. G. (2004). Mushrooms: cultivation, nutritional value, medicinal effect, and environmental impact. New York: CRC Press. http://dx.doi.org/10.1201/9780203492086.

Dadali, G., Demirhan, E., \& Ozbek, B. (2007). Microwave heat treatment of spinach: drying kinetics and effective moisture diffusivity. Drying Technology, 25(10), 1703-1712. http://dx.doi. org/10.1080/07373930701590954.

Demiray, E., \& Tulek, Y. (2015). Color degradation kinetics of carrot (Daucus carota L.) slices during hot air drying. Journal of Food Processing and Preservation, 39(6), 800-805. http://dx.doi.org/10.1111/ jfpp.12290.

Demirhan, E., \& Ozbek, B. (2009). Color change kinetics of microwavedried basil. Drying Technology, 27(1), 156-166. http://dx.doi. org/10.1080/07373930802566101.

Falade, O. K., Igbeka, J. C., \& Ayanwuyi, F. A. (2007). Kinetics of mass transfer, and colour changes during osmatic dehydration of watermelon. Journal of Food Engineering, 80(3), 979-985. http:// dx.doi.org/10.1016/j.jfoodeng.2006.06.033.

Halsey, G. (1948). Physical adsorption on non-uniform surfaces. The Journal of Chemical Physics, 16(10), 931-932. http://dx.doi. org/10.1063/1.1746689.

Henderson, S. M. (1952). A basic concept of equilibrium moisture. Agricultural Engineering, 33, 29-32.

Jwanny, E. W., Rashad, M. M., Moharib, S. A., \& El Beih, N. M. (1996). Biological evaluation of date-waste dietary fibre and Endomycopsis 
fibuligera protein with rats. Bioresource Technology, 56(2-3), 201-205. http://dx.doi.org/10.1016/0960-8524(96)00024-7.

Kostaropoulos, A. E., \& Saravacos, G. D. (1995). Microwave pretreatment for sun-dried raisins. Journal of Food Science, 60(2), 344-347. http:// dx.doi.org/10.1111/j.1365-2621.1995.tb05669.x.

Madamba, P. S., Driscoll, R. H., \& Buckle, K. A. (1996). The thin-layer drying characteristics of garlic slices. Journal of Food Engineering, 29(1), 75-97. http://dx.doi.org/10.1016/0260-8774(95)00062-3.

Maskan, M. (2001). Kinetics of colour change of kiwifruits during hot air and microwave drying. Journal of Food Engineering, 48(2), 169175. http://dx.doi.org/10.1016/S0260-8774(00)00154-0.

Microsoft Office (2016). Excel version in Microsoft Office 2016 for Windows. Washington: Microsoft Office.

Midilli, A., Kucuk, H., \& Yapar, Z. (2002). A new model for singlelayer drying. Drying Technology, 20(7), 1503-1513. http://dx.doi. org/10.1081/DRT-120005864.

Okos, M. R., Narishman, G., Singh, R. K., \& Weitnauer, A. C. (1992). Food dehydration. In D. R. Heldman \& D. B. Lund (Eds.), Handbook of Food Engineering (pp. 437-562). New York: CRC Press.

Oswin, C. R. (1946). The kinetics of package life. III. The isotherm. Journal of Chemical Technology and Biotechnology, 65(12), 419-421. http://dx.doi.org/10.1002/jctb.5000651216.

Park, K. J., Vohnikova, Z., \& Brod, F. P. R. (2002). Evaluation of drying parameters and desorption isotherms of garden mint leaves (Mentha crispa L.). Journal of Food Engineering, 51(3), 193-199. http://dx.doi. org/10.1016/S0260-8774(01)00055-3.

Politowicz, J., Lech, K., Sánchez-Rodríguez, L., Figiel, A., Szumny, A., Grubor, M., \& Carbonell-Barrachina, Á. A. (2018). Volatile composition and sensory profile of oyster mushroom as affected by drying method. Drying Technology, 36(6), 685-696. http://dx.doi.or g/10.1080/07373937.2016.1274903.
Prothon, F., \& Ahrne, L. M. (2004). Application of the Guggenheim, Anderson and De Boer model to correlate water activity and moisture content during osmotic dehydration of apples. Journal of Food Engineering, 61(3), 467-470. http://dx.doi.org/10.1016/ S0260-8774(03)00119-5.

Rama, V., \& Jacob John, P. (2000). Effect of methods of drying and pretreatments on quality of dehydrated mushroom. Indian Food Packer, 54, 25-35.

Sahin, S., \& Sumnu, S. G. (2006). Physical properties of foods. New York: Springer.

Suh, H. J., Noh, D. O., Kang, C. S., Kim, J. M. \& Lee, S. W. (2003). Thermal kinetics of color degradation of mulberry fruit extract. Nahrung/ Food, 47(2), 132-135. https://doi.org/10.1002/food.200390024.

Usami, A., Motooka, R., Nakahashi, H., Marumoto, S., \& Miyazawa, M. (2015). Chemical composition and character impact odorants in volatile oils from edible mushrooms. Chemistry \& Biodiversity, 12(11), 1734-1745. http://dx.doi.org/10.1002/cbdv.201400395. PMid:26567951.

Van Den Berg, C., \& Bruin, S. (1981). Water activity and its estimation in food systems. In L. B. Rockland \& G. F. Stewarts (Eds.), Theorical aspects in water activity: influence on food quality (pp. 12-45). New York: Academic Press. http://dx.doi.org/10.1016/B978-0-12591350-8.50007-3.

Xanthopoulos, G., Nastas, C. V., Boudouvis, A. G., \& AravantinosKarlatos, E. (2014). Color and mass transfer kinetics during air drying of pretreated oyster mushrooms (Pleurotus ostreatus spp.). Drying Technology, 32(1), 37-41. http://dx.doi.org/10.1080/07373 937.2013.811686.

Yapar, S., Helvaci, S. S., \& Peker, S. (1990). Drying behavior of mushroom slices. Drying Technology, 8(1), 77-79. http://dx.doi. org/10.1080/07373939008959865. 